\section{Acute Pancreatitis vs. Acute Recurrent Pancreatitis: Investigation of Clinical and Etiological Factors}

\author{
Akut Pankreatit ve Akut Tekrarlayan Pankreatit: \\ Klinik ve Etyolojik Faktörlerin Araştırılması
}

Ferda Özbay Hoşnut $\odot$ Gülseren Şahin ๑ Ayla Akca Çağlar ๑ Naz Güleray ๑ Derya Erdoğan ๑

\section{ABSTRACT}

Objective: It was aimed to evaluate the etiology, clinical, laboratory and imaging findings and treatment methods of patients who have admitted with acute pancreatitis (AP) and progressed to chronic pancreatitis (CP) with ARP (acute recurrent pancreatitis).

Methods: The data of children under the age of 18 years who were admitted to our hospital between January 2013-July 2020 and were diagnosed with acute, acute recurrent or chronic pancreatitis according to INSPPIRE diagnostic criteria were evaluated retrospectively.

Results: There were 77 patients who were followed-up with the diagnosis of acute pancreatitis. Pancreatitis attack did not recur in 53/77 patients and no underlying cause was found in $35.84 \%$ (19/53) of the patients. The most common factor in those whose cause could be determined was gallstones (15.1\%) (8/53). The pancreatitis attack recurred in 24 (31\%) of the patients. Congenital anomalies (9/24) and hereditary pancreatitis (5/24) were the most common causes of pancreatitis in these patients and these factors were a risk factor for the recurrence of pancreatitis attack. There was no difference between the groups in terms of complications ( $p=0.423$ ); however, chronicity was more common in the group with $\operatorname{ARP}(p=0.003)$.

Conclusion: Beside the pancreatitis is a rare disease in childhood, with the increase of awareness and increased accessibility to diagnostic imaging methods, more and more pancreatitis is diagnosed day by day. Idiopathic acute pancreatitis cases still constitute the largest group. If other causes are excluded in these cases, it is important to investigate congenital anomalies, genetic and metabolic etiologies.

Keywords: Acute pancreatitis, acute recurrent pancreatitis, etiology, children

Öz

Amaç: Çalışmamızda akut pankreatit (AP) ile başvuran ve tekrarlayan pakreatit ile kronik pankreatit (KP) ilerleyen hastaların etiyolojilerinin, klinik, laboratuvar ve görüntüleme bulgularının ve tedavi yöntemlerinin değerlendirilmesi amaçlanmıştır.

Yöntem: Ocak 2013-Temmuz 2020 yılları arasında başvuran, 18 yaşından küçük olan, INSPPIRE tanı kriterlerine göre akut, akut tekrarlayan ve kronik pankreatit tanısı alan çocukların verileri geriye dönük olarak taranmıştır

Bulgular: Akut pankreatit tanısı ile izlenen 77 hasta mevcuttur. Akut pankreatit nedeniyle başvuran ve pankreatit atağı tekrarlamayan hastaların \%35,84'ünde (19/53) altta yatan bir neden saptanmamıştır. Nedeni saptanabilenlerde en sık etken safra taş/arıdır (\%15,1) (8/53). Hastaların 24'ünde (\%31) pankreatit atağı tekrarlamıştır. Bu hastalarda konjenital anomaliler (9/24) ve kalıtsal hastalıklar (5/24) pankreatitin en sık nedenidir ve bu etkenler pankreatit atağının tekrarlaması açısından bir risk faktörüdür. Komplikasyon açısından gruplar arasında fark yoktur $(p=0,423)$, ancak akut tekrarlayan grupta kronikleşme daha fazla$\operatorname{dir}(p=0,003)$.

Sonuç: Çocukluk çağında nadir görülen pankreatitlerin sıklığı; farkındalığın ve ileri görüntüleme yöntemlerinin artması ile her geçen gün artmaktadır. En büyük hasta grubunu hala idiyopatik akut pankreatit olguları oluşturmaktadır. Bu olgularda genetik ve metabolik nedenlerin araştırılması önemlidir. Tekrarlayan pankreatitler kronik pankreatit gelişimi açııından yakından takip edilmelidir.

Anahtar kelimeler: Akut pankreatit, akut rekürren pankreatit, etyoloji, çocuklar
Received: 04.01 .2021

Accepted: 13.03 .2021

Published Online: 03.08 .2021

Cite as: Özbay Hoșnut F, Şahin G, Akca Çağlar A, Guleray N, Erdoğan D. Acute pancreatitis vs. acute recurrent pancreatitis: Investigation of clinical and etiological factors. İzmir Dr. Behçet Uz Çocuk Hast. Dergisi. 2021;11(2):147-52.

Ferda Özbay Hoşnut Dr. Sami Ulus Kadın Doğum, Çocuk Sağlığı ve Hastalıkları Eğitim ve Araştırma Hastanesi, Çocuk Gastroenteroloji, Hepatoloji ve Beslenme Kliniği, Ankara, Türkiye ferdaozbay72@yahoo.com ORCID: 0000-0002-4549-7474

G. Şahin 0000-0001-6146-3509 Dr. Sami Ulus Kadın Doğum, Çocuk Sağlığı ve Hastalıkları Eğitim ve Araştırma Hastanesi, Çocuk Gastroenteroloji, Hepatoloji ve Beslenme Kliniği, Ankara, Türkiye

A.A. Çağlar 0000-0002-3312-2448 Ankara Şehir Hastanesi, Çocuk Acil Kliniği, Ankara, Türkiye

N. Güleray 0000-0001-7683-371X Dr. Sami Ulus Kadın Doğum, Çocuk Sağlığı ve Hastalıkları Eğitim ve Araştırma Hastanesi, Tıbbi Genetik Bölümü, Ankara, Türkiye

D. Erdoğan 0000-0003-1730-4177 Dr. Sami Ulus Kadın Doğum, Çocuk Sağlığı ve Hastalıkları Eğitim ve Araştırma Hastanesi, Çocuk Cerrahisi Kliniği, Ankara, Türkiye 


\section{INTRODUCTION}

In children, incidence of acute pancreatitis (AP) has reached up to $13 / 100,000$ in the last twenty years, which approaches the incidence reported in adults. The increase in incidence rates may represent a true increase or enhanced awareness in childhood pancreatitis ${ }^{(1)}$. Episodes of acute pancreatitis do not recur in most children. Single-center studies have shown that $15-35 \%$ of children with AP develop acute recurrent pancreatitis (ARP), and the annual incidence of chronic pancreatitis (CP) is $0.5 / 100,000$ (2). The factors that predispose to emergence of recurrent episodes of AP and progression from ARP to $C P$ are unknown. While the majority of episodes of pancreatitis in adults are associated with gallstones or alcohol, etiologic factors in children are much more diverse ${ }^{(3)}$. A multicenter cross-sectional study performed by the International Study Group of Pediatric Pancreatitis (INSPPIRE) has indicated genetic variations as risk factors among patients with ARP and CP, showing that smoking and alcohol abuse is rare in this population ${ }^{(4)}$.

In our study, we evaluated the etiology, clinical, laboratory, and imaging findings and treatment methods of patients who were admitted with acute pancreatitis (AP) which progressed to chronic pancreatitis (CP) with ARP.

\section{MATERIAL and METHOD}

A retrospective study was conducted in a pediatric gastroenterology, hepatology and nutrition department at a tertiary-care hospital. The children under the age of 18 years with accessible archive records and presented with the diagnosis of pancreatitis according to INSPPIRE diagnostic criteria, between January 2013 and July 2020 were included in the study. The study protocol has been approved by our hospital ethics committee on human research with the decision number E-20/12-60.

Acute pancreatitis was defined based on the presence of typical abdominal pain, serum amylase and/or lipase levels $\geq 3$ times higher than normal, and 2 findings suggestive of acute pancreatitis as revealed by radiological imaging techniques. Acute recurrent pancreatitis was defined based on the presence of 2 or more attacks in which all symptoms resolve completely between attacks. Chronic pancreatitis was defined according to characteristic imaging findings associated with typical abdominal pain or exocrine or endocrine pancreatic insufficiency (5). The demographic characteristics, clinical and laboratory findings, imaging methods and causes of the pancreatitis of the patients were retrospectively retrieved from electronic records.

\section{Statistical analysis}

The data obtained were evaluated using "SPSS version 20.0 program". Descriptive statistics were stated as number, percentage (\%), ratio, median, mean, standard deviation. For numerical variables with normal distribution between two groups Student's T-test, for variables that do not conform to the normal distribution Mann-Whitney U-test and for categorical variables chisquare test were used, respectively. Statistical significance was accepted as $p<0.05$.

\section{RESULTS}

A total of 77 patients including 44 (44\%) male, and $43(56 \%)$ female patients followed up with a diagnosis of acute pancreatitis were included in the study. The mean age of the patients at the first AP attack was $11.12 \pm 4.78$ (min. 2 months-max. 18 years) years. The most common complaints of the patients were abdominal pain (88\%), nausea, and vomiting (32.5\%). The median duration of these complaints was 3 ( $\mathrm{min}$. 1-max. 30) days. An underlying cause was not found in $29.9 \%(23 / 77)$ of the patients. The most common etiological factors were congenital anomalies (19.5\%), gallstones $(11.7 \%)$, infections $(9.1 \%)$, trauma $(7.8 \%)$, and hereditary pancreatitis (7.8\%).

Attacks of pancreatitis recurred in 24 (31\%) of the patients. The median time to the recurrence of the attack was 137.5 (minimum 13, maximum 840) days. Nine (37.5\%) male,and 15 (67.5\%) female patients had recurrent attacks of acute pancreatitis. Gender was not a risk factor for the recurrence of pancreatitis attack ( $p=0.467)$. 
The etiological factor could not be found in $35.84 \%(19 / 53)$ of the patients who were admitted with acute pancreatitis without recurrent bouts, and in $(15.1 \%)(8 / 53)$ of these cases, gallstones was determined to be the most common etiology (Table 1). In 6 patients in this group, due to the severe course of the disease and the development of complications, genetic studies were performed including sequencing of CFTR (cystic fibrosis transmembrane conduction modifier), PRSS1 (cationic trypsinogen), and SPINK1 (serine protease inhibitor Kazal type 1).

Congenital anomalies $(9 / 24)$ and hereditary pancreatitis $(5 / 24)$ were the most common causes of

Table 1. Causes of acute pancreatitis.

\begin{tabular}{|c|c|}
\hline Etiology & $(n: 53)(\%)$ \\
\hline Idiopathic & $19(35.84)$ \\
\hline $\begin{array}{l}\text { Congenital anomalies } \\
\text { Choledochal cyst }(n: 3) \\
\text { Pancreaticobiliary junction anomaly, } \\
\text { choledochal cyst }(n: 2) \\
\text { Stenosis in the choledoch }(n: 1)\end{array}$ & $6(11.3)$ \\
\hline $\begin{array}{l}\text { Hereditary pancreatitis } \\
\text { CFTR mutation }\end{array}$ & 1 (1.9) \\
\hline Gallstones & $8(15.1)$ \\
\hline $\begin{array}{l}\text { Infections } \\
\text { EBV infection + Kawasaki disease (n:1) } \\
\text { Hepatitis A ( } \mathrm{n}: 1) \\
\text { Mumps }(\mathrm{n}: 1) \\
\text { Mycoplasma }(\mathrm{n}: 4)\end{array}$ & $7(13.2)$ \\
\hline $\begin{array}{l}\text { Trauma } \\
\text { Direct trauma }(\mathrm{n}: 5) \\
\text { Duodenal hematoma developing after upper } \\
\text { GIS endoscopy }(\mathrm{n}: 1)\end{array}$ & $6(11.3)$ \\
\hline $\begin{array}{l}\text { Metabolic causes } \\
\text { ApoC2 deficiency }\end{array}$ & 1 (1.9) \\
\hline $\begin{array}{l}\text { Medicines } \\
\text { L-asparginase }(n: 1) \\
\text { Bismuth subcitrate }(n: 1)\end{array}$ & $2(3.8)$ \\
\hline $\begin{array}{l}\text { Endocrine causes } \\
\text { Type } 1 \mathrm{DM}+\text { dyslipidemia }\end{array}$ & 1 (1.9) \\
\hline $\begin{array}{l}\text { Other } \\
\text { Sclerosing cholangitis+autoimmune } \\
\text { pancreatitis }(\mathrm{n}: 1) \\
\text { Acute lymphoblastic leukemia }(\mathrm{n}: 1)\end{array}$ & $2(3.8)$ \\
\hline
\end{tabular}

Table 2. Causes of acute recurrent pancreatitis.

\begin{tabular}{|c|c|}
\hline Etiology & $(n: 24)(\%)$ \\
\hline Idiopathic & 4 (16.6) \\
\hline $\begin{array}{l}\text { Congenital anomalies } \\
\text { Pankreas divisum ( } \mathrm{n}: 2) \\
\text { Pankreas divisum+CTFR mutation ( } \mathrm{n}: 2) \\
\text { Pankreas divisum+SPINK1 mutation }(\mathrm{n}: 1) \\
\text { Annular pankreas +atypical gallbladder }(\mathrm{n}: 1) \\
\text { Pancreaticobiliary junction anomaly, } \\
\quad \text { choledochal cyst } \mathrm{n} \text { : }(2) \\
\text { Pancreaticobiliary junction anomaly, } \\
\text { choledochal cyst +CTFR mutation ( } \mathrm{n}: 1)\end{array}$ & 9 (37.5) \\
\hline $\begin{array}{l}\text { Hereditary pancreatitis } \\
\text { CFTR mutation }(\mathrm{n}: 1) \\
\text { PRSS } 1 \text { mutation }(\mathrm{n}: 2) \\
\text { SPINK1 mutation }(\mathrm{n}: 2)\end{array}$ & $5(20.8)$ \\
\hline Gall stones & $1(4.2)$ \\
\hline $\begin{array}{l}\text { Metabolic factors } \\
\text { Type } 1 \text { hyperlipidemia ( } \mathrm{n}: 1) \\
\text { Type } 4 \text { hyperlipidemia +gallstone (n:1) } \\
\text { Izovaleric acidemia ( } \mathrm{n}: 1)\end{array}$ & $3(12.5)$ \\
\hline $\begin{array}{l}\text { Endocrine causes } \\
\qquad \text { Hypercalcemia (CASR gene mutation) }\end{array}$ & $1(4.2)$ \\
\hline $\begin{array}{l}\text { Other factors } \\
\text { Torsion of the wandering spleen, torsion of } \\
\text { the stomach and sigmoid colon }\end{array}$ & $1(4.2)$ \\
\hline
\end{tabular}

pancreatitis in patients with recurrent pancreatitis attacks (Table 2). Genetic studies were performed in 11 patients and concomitant hereditary pancreatitis was diagnosed in 4 patients with congenital anomalies.

While congenital anomalies and hereditary pancreatitis were seen in $37.5 \%(9 / 24)$ and $20.8 \%$ $(5 / 24)$ of the patients in the group with, and $11.3 \%$ $(6 / 53)$ and $1.9 \%(1 / 53)$ of the patients without recurrent bouts of pancreatitis. The differences between the two groups regarding these etiologies $(p=0.012, p=0.01$ ) were statistically significant.

When patients with acute pancreatitis and ARP are compared in terms of clinical and laboratory features, AST, GGT, and direct bilirubin values were found to be higher in the group of patients with AP $(\mathrm{p}<0.05)$ (Table 3).

Seventeen (22.1\%) patients were followed only by abdominal ultrasonography (USG) and other 
imaging modalities including computed tomography (CT), magnetic resonance cholangiopancreatography (MRCP), endoscopic retrograde cholangiopancreatography (ERCP) were not performed. Advanced imaging in addition to ultrasonography was performed in $71.7 \%(38 / 53)$, and $87.5 \%(21 / 24)$ of the patients followed up with the diagnosis of AP and ARP, respectively. There was no difference between the groups in terms of diagnostic methods ( $p=0.156)$.

All patients received intravenous fluid-electrolyte support and pain control was provided. Cholecystectomy was performed in 5 patients with gallstones ( 3 patients with AP, and 2 with ARP). Reduction of gastro-sigmoid volvulus, splenic detorsion, gastropexy, and splenopexy were

Table 3. Clinical and laboratory features of patients with acute pancreatitis and ARP.

\begin{tabular}{|c|c|c|c|}
\hline & $\begin{array}{l}\text { AP group } \\
(n: 53)(\%)\end{array}$ & $\begin{array}{l}\text { ARP group } \\
(\mathrm{n}: 24)(\%)\end{array}$ & $\begin{array}{c}\mathrm{P} \\
\text { values }\end{array}$ \\
\hline \multicolumn{4}{|l|}{ Gender } \\
\hline Boys & $25(47.2)$ & $9(37.5)$ & 0.295 \\
\hline Girls & $28(52.8)$ & $15(62.5)$ & \\
\hline Age (years) & $11.12 \pm 5.1$ & $11.28 \pm 4.35$ & 0.849 \\
\hline \multicolumn{4}{|l|}{ Symptomps } \\
\hline Abdominal pain & $45(84.9)$ & $23(95.8)$ & 0.259 \\
\hline Nausea, vomitting & $18(34)$ & $7(29.2)$ & 0.795 \\
\hline Jaundice & $2(3.8)$ & 0 & 1.0 \\
\hline $\begin{array}{l}\text { Discomfort (1), conscio- } \\
\text { usness (1), diaerrhea (1) }\end{array}$ & $3(5.7)$ & 0 & 0.548 \\
\hline Symptom duration (day) & $6.07 \pm 7.16$ & $13.52 \pm 38.8$ & 0.39 \\
\hline AST (U/L) & $76.61 \pm 113.13$ & $34.43 \pm 35.83$ & 0.018 \\
\hline $\operatorname{ALT}(U / L)$ & $74.03 \pm 119.63$ & $37.33 \pm 65.45$ & 0.089 \\
\hline GGT (U/L) & $104.77 \pm 169.12$ & $57.85 \pm 98.26$ & 0.042 \\
\hline Total bilirubin (mg/dL) & $1.73 \pm 3.70$ & $0.86 \pm 0.61$ & 0.253 \\
\hline Direct bilirubin $(\mathrm{mg} / \mathrm{dL})$ & $0.79 \pm 1.79$ & $0.25 \pm 0.23$ & 0.036 \\
\hline Amilase (U/L) & $1086.98 \pm 13$ & $804.50 \pm 819.37$ & 0.343 \\
\hline Lipase (U/L) & $1623.09 \pm 17$ & $1334.62 \pm 14$ & 0.482 \\
\hline White blood cell & $12.056 \pm 4287$ & $10.400 \pm 2882$ & 0.096 \\
\hline Sedimentation (mm/hour) & $31.35 \pm 24.64$ & $32.41 \pm 28.26$ & 0.893 \\
\hline CRP (mg/L) & $36.62 \pm 56.66$ & $35.01 \pm 54.43$ & 0.950 \\
\hline HDL (mg/dl) & $47.45 \pm 38.23$ & $37.26 \pm 15.57$ & 0.244 \\
\hline Total cholesterol mg/dl) & $157.89 \pm 123.48$ & $142.04 \pm 39.88$ & 0.569 \\
\hline Triglyceride (mg/dl)t & $133.75 \pm 216.41$ & $329.52 \pm 880.41$ & 0.326 \\
\hline
\end{tabular}

Table 4. Methods used in pancreatitis treatment.

\begin{tabular}{lccc}
\hline Treatment method & $\begin{array}{c}\text { AP group } \\
\mathbf{n}(\%)\end{array}$ & $\begin{array}{c}\text { ARP group } \\
\mathbf{n}(\%)\end{array}$ & $\begin{array}{c}\text { P } \\
\text { values }\end{array}$ \\
\hline Interventional & $8(15.1)$ & $8(33.3)$ & 0.078 \\
Surgery & $3(5.7)$ & $2(8.3)$ & 0.644 \\
\hline
\end{tabular}

performed on the patient with wandering spleen and secondary gastric-sigmoid volvulus and splenic torsion. ERCP was performed in 16 patients (8 patients from each group) for treatment purposes. A stent was placed in the narrow segment of the pancreatic duct of 10 patients using ERCP, and gallstone was removed in 6 patients. There was no difference between the groups in terms of treatment options ( $p>0.05$ ) (Table 4).

Complications were observed in $7(13.2 \%)$ patients with AP during the follow-up. These complications included pancreatic necrosis in 2 , necrosis, peritonitis and pseudocyst formation in the pancreas in 1 , splenic vein thrombosis, infarction and pseudocyst formation in the spleen in 1 , necrosis in the pancreas, infarction of spleen and splenic vein thrombosis in 1 , acute liver failure in 1, and intra-abdominal abscess in 1 patient. Chronic pancreatitis developed in only $3.7 \%(2 / 53)$ of the patients.

While pancreatic necrosis was observed in 1 (4.16\%) patient with acute recurrent pancreatitis, chronic pancreatitis (7/24) developed in $29.16 \%$ of the patients. However there was no difference between the groups in terms of complications $(p=0.423)$. Whereas chronicity was statistically more common in the recurrent AP group $(p=0.003)$. None of our patients who were followed up with a diagnosis of pancreatitis exited.

\section{DISCUSSION}

The most common symptom in children with acute pancreatitis is abdominal pain (80-95\%), especially in the epigastric region ${ }^{(6)}$. The second most common symptom is nausea and vomiting, which has been reported in $40-80 \%$ of patients ${ }^{(7-9)}$. Additionally, the most common symptoms in our patients were also abdominal pain, nausea and vomiting in concordance with the literature.

Despite better diagnostic methods and increased awareness for the etiologies of pancreatitis, surprisingly, the proportion of patients diagnosed with idiopathic pancreatitis did not decrease. Studies have shown that the proportion of patients with idiopathic pancreatitis varies between $13 \%$ and $34 \%$. 
Examination of the current data shows that other important causes of AP in children are biliary diseases (gallstones and bile duct diseases), drugs, systemic diseases, and trauma, followed by infectious, metabolic and hereditary pancreatitis ${ }^{(3,8,10)}$. In our study, no definitive cause was found in $29.8 \%$ (23/77) of the patients who presented with pancreatitis. But in $70.2 \%$ of them identifiable risk factors were found for AP including congenital anomalies, gallstones, infection, trauma, and hereditary pancreatitis as stated in previous studies.

Pancreatitis attacks recurred in 24 (31\%) of our patients during follow-up. This rate falls within the range of previously published recurrence rates of $7-34 \%{ }^{(3)}$. Sweeny et al. ${ }^{(10)}$ stated that in $70 \%$ of their patients, bouts of recurrent pancreatitis developed within the first 5 months after onset of AP and this finding could be helpful in could be helpful in the parental counseling of pediatric patients presenting with the first AP attack. Similarly, the median time elapsed till the development of a second pancreatitis attack in our study was 4.5 months.

CFTR, PRSS1 and SPINK1 mutations and genetic changes in other genes that cause hereditary pancreatitis, are considered to be the most common risk factors in children with acute recurrent pancreatitis and $\mathrm{CP}{ }^{(11)}$. Another risk factor is obstructive causes primarily involving pancreatic divisum ${ }^{(12)}$. Pancreatic divisum is found in $7 \%$ of the general population. Interestingly, it is found in almost half of the patients with pancreatitis who harbor genetic mutations (mainly CFTR mutations) and pancreatitis. This suggests that the pancreatic divisum synergizes with genetic mutations to cause $\mathrm{ARP}$ and $\mathrm{CP}{ }^{(2)}$. The most common causes were congenital anomalies and hereditary pancreatitis in our patients with recurrent pancreatitis attacks. The most common congenital anomaly was pancreatic divisum in 5 patients, and $60 \%$ (3/5) of them had accompanying genetic mutations. Our results support the hypothesis that genetic factors are is one of the strongest risk factors strongly contribute to the etiopathogenesis underlying ARP. The limitation of our study is that genetic analysis was not performed on all our patients, because of the higher cost of genetic testing compared to other laboratory studies and consideration of a step-by-step approach for the etiological factors as genetic studies were planned after other causes of pancreatitis have been excluded.

In our study, no difference was found between the children with the diagnoses of AP and ARP in terms of demographic and clinical findings. When laboratory findings were compared, it was seen that AST, GGT and total bilirubin values were higher in patients with AP. It was thought that this situation was caused by the fact that obstructive pathologies as gallstones $(n: 8)$, pancreaticobiliary compound anomaly $(n: 6)$ and other reasons (1 patient with duodenal hematoma) were more common in patients with AP.

Endoscopic retrograde cholangiopancreatography is a method used for the diagnosis and treatment. Common indications for using ERCP in children are biliary obstructions and pancreatitis ${ }^{(13)}$. In our study ERCP was performed 16 patients so as to stent the narrow segment and remove stones. Among them 10 patients had congenital pancreaticobiliary anomalies such as pancreatic divisum, common bile duct cyst, pancreaticobiliary composition anomaly, and annular pancreas, and 2 had mutations causing hereditary pancreatitis.

Unlike adults, only a small percentage of pediatric patients have been reported to have serious complications ${ }^{(3)}$. These complications are sterile and infected collections, fistulas, and vascular complications ${ }^{(14)}$. Complications developed in $13.2 \%$ of our patients whose pancreatitis attack did not recur. While there was no difference between the groups in terms of complications $(p=0.423)$, it was found that chronicity was statistically higher in the acute recurrent group $(p=0.003){ }^{(15)}$. Despite the hypotheses stating that recurrent acute pancreatitis attacks may turn into $C P$, there are no data on the conversion of ARP to $\mathrm{CP}$ in children, excepting possibly the cases with hereditary pancreatitis ${ }^{(16)}$. Poddar et al. ${ }^{(17)}$ reported that 37 (42\%) of 88 children with ARP developed CP and therefore, ARP is the precursor of the chronic process and chronicity is associated with idiopathic etiology and genetic 
mutations. Our study supports this thought as $29.16 \%$ of our patients with ARP developed chronic pancreatitis and recurrent attacks were the precursors of a chronic pancreatitis.

\section{CONCLUSION}

Nowadays, greater number of children receive the diagnosis of pancreatitis thanks to the increase in awareness and accessibility to diagnostic imaging methods. However, in a significant portion of the cases, still a specific cause cannot be determined. In our study, in $29.8 \%$ of the patients a defined etiologic factor could not be found. Congenital anomalies of the pancreas and biliary tract and genetic causes have been found to be important etiologic factors for pancreatitis. For this reason, further investigations including MRCP, ERCP and genetic examinations are necessary to clarify the etiology of pancreatitis. In our study, it was determined that the most common complication in AP and ARP was pancreatic necrosis. Patients with pancreatitis should be closely followed up with clinical findings and, if necessary, laboratory examinations should be performed to determine the risk of serious complications. Although there was no difference between the groups in terms of the risk of developing complications, it was found that chronicity was more common in ARP cases. Long-term followup of recurrent acute pancreatitis cases is extremely important so as to prevent development of the risk of chronic pancreatitis and pancreatic insufficiency.

Ethics Committee Approval: Dr. Approval was obtained from the ethics committee of Sami Ulus Gynecology, Obstetrics and Gynecology Training and Research Hospital (16/12/2020,E-20/12-60).

Conflict of Interest: The authors declare no conflicts of interest.

Funding: None.

Informed Consent: None.

\section{REFERENCES}

1. UC A, Husain SZ. Pancreatitis in children. Gastroenterology. 2019;156(7):1969-78.

https://doi.org/10.1053/j.gastro.2018.12.043
2. Pohl JF, UcA. Paediatric pancreatitis. Curr Opin Gastroenterol. 2015;31(5):380-6. https://doi.org/10.1097/MOG.0000000000000197

3. Bai HX, Lowe ME, Husain SZ. What have we learned about acute pancreatitis in children? J Pediatr Gastroenterol Nutr. 2011;52(3):262-70.

https://doi.org/10.1097/MPG.0b013e3182061d75

4. Kumar S, Ooi CY, Werlin S, et al. Risk Factors Associated With Pediatric Acute Recurrent and Chronic Pancreatitis: Lessons From INSPPIRE. JAMA Pediatr. 2016;170(6):562-9. https://doi.org/10.1001/jamapediatrics.2015.4955

5. Morinville VD, Husain SZ, Bai H, et al. Definitions of pediatric pancreatitis and survey of present clinical practices. J Pediatr Gastroenterol Nutr. 2012;55(3):261-5. https://doi.org/10.1097/MPG.0b013e31824f1516

6. Malathi Sathiyasekaran, Vishnu Biradar, Ganesh Ramaswamy, et al. Pancreatitis in Children.Indian J Pediatr. 2016;83(1213):1459-72. https://doi.org/10.1007/s12098-016-2115-1

7. Werlin SL, Kugathasan S, Frautschy BC. Pancreatitis in children. J Pediatr Gastroenterol Nutr. 2003;37(5):591-5. https://doi.org/10.1097/00005176-200311000-00017

8. Sánchez-Ramírez CA, Larrosa-Haro A, Flores-Martínez S, Sánchez-Corona J, Villa-Gómez A, Macías-Rosales R. Acute and recurrent pancreatitis in children: etiological factors. Acta Paediatr. 2007;96(4):534-7.

https://doi.org/10.1111/j.1651-2227.2007.00225.x

9. Yeung $\mathrm{CY}$, Lee HC, Huang FY, et al. Pancreatitis in children-experience with 43 cases. Eur J Pediatr. 1996;155(6):45863. https://doi.org/10.1007/BF01955181

10. Sweeny KF, Lin TK, Nathan JD, et al. Rapid Progression of Acute Pancreatitis to Acute Recurrent Pancreatitis in Children. J Pediatr Gastroenterol Nutr. 2019;68(1):104-9. https://doi.org/10.1097/MPG.0000000000002145

11. Kumar S, Ooi CY, Werlin S, et al. Risk Factors Associated With Pediatric Acute Recurrent and Chronic Pancreatitis: Lessons From INSPPIRE. JAMA Pediatr. 2016;170(6):562-9. https://doi.org/10.1001/jamapediatrics.2015.4955

12. Lin TK, Abu-El-Haija M, Nathan JD, et al. Pancreas Divisum in Pediatric Acute Recurrent and Chronic Pancreatitis: Report From INSPPIRE. J Clin Gastroenterol. 2019;53(6):e232-8. https://doi.org/10.1097/MCG.0000000000001063

13. Darge K, Anupindi S. Pancreatitis and the role of US, MRCP and ERCP. Pediatr Radiol. 2009;39(Suppl 2):S153-7. https://doi.org/10.1007/s00247-009-1145-5

14. Restrepo R, Hagerott HE, Kulkarni S, Yasrebi M, Lee EY. Acute Pancreatitis in Pediatric Patients: Demographics, Etiology, and Diagnostic Imaging. AJR Am J Roentgenol. 2016;206(3):632-44. https://doi.org/10.2214/AJR.14.14223

15. Fonseca Sepúlveda EV, Guerrero-Lozano R. Acute pancreatitis and recurrent acute pancreatitis: an exploration of clinical and etiologic factors and outcomes. J Pediatr (Rio J). 2019;95(6):713-9. https://doi.org/10.1016/j.jped.2018.06.011

16. Schneider A, Whitcomb DC. Hereditary pancreatitis: a model for inflammatory diseases of the pancreas. Best Pract Res Clin Gastroenterol. 2002;16(3):347-63. https://doi.org/10.1053/bega.2002.0311

17. Poddar U, Yachha SK, Borkar V, Srivastava A. Is acute recurrent pancreatitis in children a precursor of chronic pancreatitis? A long-term follow-up study of 93 cases. Dig Liver Dis. 2017;49(7):796-801. https://doi.org/10.1016/j.dld.2017.02.019 